Чy $\Lambda$.

\title{
ЭТАПЫ РАЗВИТИЯ
}

И ПЕРСПЕКТИВЫ СОТРУАНИЧЕСТВА МЕЖАУ КНР И РФ В СФЕРЕ ЭНЕРГЕТИКИ

\begin{abstract}
Аннотация. Автор статьи исследует основные правовые документы сотрудничества в сфере энергетики между Китаем и Россией и развитие отночений КНР и РФ как стратегических партнеров. Раскрыты основные этапы развития энергетических переговоров Китая и России. Развитие энергетического сотрудничества между Китаем и Россией разделено на четыре этапа: период Ельиина, эпоха Путина, эра Медведева, новая эра Путина. В статье отмечается, ито энергетическое сотрудничество между Китаем и Россией является важной составной частью стратегического сотрудничества обеих сторона. В данной работе методологические основы помитических исследований могут быть определены как системный, структурно-функциональный, сравнительно-политический подходы, методы анализа, синтеза. Научная новизна исследования заключается в том, что долгосрочные перспективы энергетического сотрудничества между Китаем и Россией зависят от трех факторов политического характера. Во-первых, сотрудничество должно опираться надвухсторонние интересь; во-вторых, энергетическое сотрудничество между двумя странами должно опираться на сильное стратегическое партнерство, которое обеспечит более широкую поддержку для энергетического диалога Китая и России. Наконеи, мидеры обоих государств должны обратить большое внимание на энергетические отношения и оказывать рещительную политическую поддержку их развитию.

Ключевые слова: энергетическое сотрудничество, энергетическая безопасность, стратегчческое партнерств, Совместное заявление, этапы развития, восточныймарирут, западныймарирут, перспективы сотрудничества, диверсификачия поставок, газовое сотрудничество.
\end{abstract}

K итай явцяется одним из крупнейших торговых партнеров России. Энергетический элемент играет значительную роль в отношениях межау Китаем и Россией не только в сфере экономики, но и в помитике, и Аипмоматии. Укрепление энергетического сотрудничества Китая и России оказывает большое вмияние на энергетическую безопасность в Азиатско-Тихоокеанском регионе. Китай явмяется крупнейшим в мире потребителем энергоресурсов, а Россия крупнейшим экспортером мира. Это связано не только с объемом торговых отношений, но и с энергетической безопасностью обеих стран. Несмотря на развитие энергетического сотруаничества Авух стран, вопросы о ценообразовании и условиях соглашения часто не совсем отчетливы, в связи с чем возникают споры. Такие споры явцяются неотъемкемой частью сотруаничества в сфере энергетики, и в большинстве случаев они связаны с поли- тическими и экономическими аспектами. Изменения на глобальном энергетическом рынке принесут много возможностей ААя энергетического сотрудничества Авух стран.

Межау Китаем и Россией, крупнейшим импортером и крупнейшим экспортером энергетики, отмечается взаимо-дополняемость во многих сферах, что укрепляет энергетическую безопасность Авух стран. Китай и Россия имеют большие потенциалы энергетического сотрудничества, оно вышио на новый уровень после госуАарственного визита в Москву Си Цзиньпина в 2013 году. СотруАничество Китая и России в энергетической сфере можно разделить на четыре этапа: периоА Ельцина, эпоха Путина, эра Медведева, новая эра Путина.

Первым большим шагом впереА в развитии отношений Китая и России стал госуАарственный визит Президента РФ Б. ЕАьцина в Пекин в Аекабре 1992 г. ГАавы Авух 
госуАарств поАПисами совместную Аекмарацию об основах взаимоотношений межАу РФ и КНР. На этом этапе формирова ись основные принципы всестороннего сотруаничества на основе стратегических партнёрских взаимоотношений межАу Китаем и Россией, а так же в сфере энергетики.

С 17 по 19 декабря 1992 года Президент Российской ФеАерации Б. Н. ЕАьцин впервые совершим официальный госуАарственный визит в Китай. В ходе визита Б. ЕАьцин встретился с ПредсеАателем КНР Ян Шанкунем (1988-1993 гг.) и Генерамьным секретаремЦК КПКЦзян Цзэминем. Аидеры Авух стран поАписали «Совместную Аекмарацию об основах взаимоотношений межАу Китайской Народной Республикой и Российской ФеАерацией», в которой зафиксировали новый уровень отношений между Авумя странами: стороны рассматривают Аруг Аруга в качестве Аружественных госуаарств.

Со 2 по 6 сентября 1994 года избранный ПредсеАатель КНР Цзян Цзэминь нахоАился в Российской ФеАерации с госуАарственным визитом. Межау ПреАсеАателем КНР Цзян Цзэминем и Президентом РФ Б. Ельциным быма подписана «Совместная китайско-российская декмарация», в которой была провозглашена решимость Авух стран развивать отношения конструктивного партнерства, ориентированные на XXI век. Эти отношения не носят союзнического характера, и не направлены против третьих стран ${ }^{[6]}$.

В ноябре 1994 года Китайская национамьная нефтегазовая корпорация и СибирскоАахьневосточная нефтяная компания России поАписа и «Меморандум переговоров» и Россия первой преАложима построить нефтепровод из Ангарска в Маньчжурию Ао города Аацин в Китае (Ангарск-Аацин). После распада СССР экономическое сотруАничество межАу Китаем и Россией, хотя и развива$\Lambda$ ось, но в целом остава ось на низком уровне, особенно в сфере энергетики. Таким образом, проект прокмаАки нефтепровоАа способствовам общему развитию сотруАничества Авух стран и повышению уровня в энергетической сфере межАу странами ${ }^{[5]}$.

С 24 по 26 апреля 1996 года Президент РФ Б. ЕАьцин находился в Китае с официальным визитом и провел переговоры с ПредсеАатемем КНР Цзян Цзэминем о развитии отношений партнерства, стратегического взаимоАействия межАу Китаем и Россией, усимения сотруаничества в разных областях. 25 апреля 1996 гола Б. ЕАьциным и Цзян Цзэмином бым поАписан Аоговор — «Совместная китайскороссийская Аекмарация», в которой было провозглашено решение развивать отношения равноправного Аоверительного партнерства, направленного на стратегическое взаимодействие в XXI веке, и определены основные принципы отношений стратегического партнерства Китая и России: «равноправие и Аоверие, АобрососеАство и Аружба, взаимовыгодное сотрУАничество» ${ }^{[7]}$.

«Совместная китайско-российская Аекмарация», поАписанная в 1996 году, явмяется оАним из важных этапов в переговорахпо развитию отношений межАу Китаем и Россией. Китай и Россия сформировахи официамьные государственные отношения стратегического партнерства. В периоА визита Б. Ельцина в Пекин, главы Китая и России подписали «Общее согмашение о сотрудничестве в энергетической сфере Китая и России», в том числе проект строительства нефтепровода и газопровода из Восточной Сибири в Китай. Можно сказать, что это «Общее соглашение» стацо премюАией энергетического сотруАничества ${ }^{[1]}$.

С 1992 года ао 1999 года сотруаничество в нефтяной сфере межАу Китаем и Россией постепенно развиванось. В период правления ЕАьцина (1992-1999 гг.), энергетическое сотруаничество межАу Авумя странами можно охарактеризовать следующим образом. Вопервых, энергетическое сотруаничество все еще было на низком уровне. Так, например, Ао 1999 года нефтяная торговмя не Аостигла 572 тыс. тонн; во-вторых, Китай импортирова

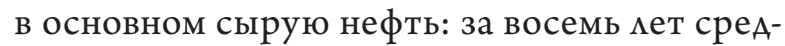
ний гоАовой объем импорта Аостиг $1.518 \mathrm{м \Lambda н.}$ тонн, в то время как среАнегодовой импорт сырой нефти за тот же периоА составим всего 203 тыс. тонн; в-третьих, несмотря на то, что торговм в энергетической сфере между Авумя странами в этот период находимась на низком уровне, но всё же, можно сказать, что это быма тенденция постепенного роста. 
В 21-м веке отношения Китая и России вступили в новый этап. Этап с 2000-2008 годы характеризуется продолжением укрепления и развития правовой базы энергетического сотрудничества межАу Китаем и Россией в рамках стратегического партнёрства.

Аесять мет - с 1992 по 2002 годы явикись основополагающим этапом развития китайско-российских отношений после окончания холодной войны. «Аоговор межАу Российской Федерацией и Китайской НароАной Республикой о добрососеАстве, Аружбе и сотрудничестве» явмяется важной вехой в истории китайско-русских отношений. Он занимает важное место в североазиатском регионе в развитии Авусторонних отношений и преАставляет арену Аля развития отношений стратегического сотрудничества межАу Китаем и Россией.

В июле 2001 года ПреАсеАатель КНР Цзян Цзэминь находился в РФ с государственным визитом. 16 июля межАу ПреАсеАателем Китая Цзян Цзэминем и Президентом России В.В. Путиным были проведены переговоры, по итогам которых стороны поАписали «Аоговор о АобрососеАстве, Аружбе и сотруАничестве межАУ КНР и РФ» и «Московское совместное заявмение глав государств Китая и России».

«Аоговор межАу Российской ФеАерацией и Китайской Народной Республикой о АобрососеАстве, Аружбе и сотруаничестве» явАяется основным программным документом, в котором было определено Аолгосрочное развитие российско-китайского стратегического сотрудничества и заложена прочная юриАическая основа зАорового и стабильного наращивания Авусторонних связей в начале 21-го века.

В 2004 году проект газопровода из России в Китай впервые стал главной темой во время визита Путина в Китай. Нефтегазовые компании России и Китайская национальная нефтегазовая корпорация подписали соглашение о стратегическом сотрудничестве, обе стороны решили созАать совместную рабочую группу по продвижению проекта газопровода.

В 2005 году Китай и Россия провели переговоры о сотруаничестве в области при- родного газа, обе стороны решили создать рабочую группу, чтобы начать строительство газопровода межАу Авумя странами. Но, с точки зрения китайских специалистов, переговоры межау Китаем и Россией в области энергетического сотрудничества не были успешными, сотруАничество в газовой сфере также столкнулось со многими труАностями и проблемами.

В марте 2007 года Президент России ВАаАимир Путин и ПреАсеАатель КНР Ху Цзиньтао подписали «Совместную Аекларацию», которая поААерживает реализацию крупных Авусторонних проектов в энергетической сфере как направление стратегии взаимовыгоАного сотруАничества.

26-28 марта 2007 года ПреАсеАатель КНР Ху Цзиньтао совершим официальный визит в РФ. ГАавы КНР и РФ провели переговоры в Москве. Визит Председателя КНР в России стал новым крупным шагом в развитии Авусторонних отношений партнерства и стратегического взаимодействия. Он позволим еще больше укрепить взаимное доверие межАу Россией и Китаем, вывести его на новую ступень, отвечающую нынешнему высокому уровню сотрудничества Авух стран в практических областях, их взаимодействию на межАународной арене. ГАавы Авух государств с уАовлетворением отметили, что за десять кет с момента установмения российско-китайских отношений партнерства и стратегического взаимодействия они поступательно развиваАись во всех сферах, принося практическую пользу народам обеих стран. Аальнейшее всестороннее укрепление сотруаничества России и Китая служит высшим национацьным интересам обоих государств, подАержанию мира и стабильности в Азиатско-Тихоокеанском регионе и во всем мире.

23 мая 2008 по приглашению преАсеАателя КНР ХУ Цзиньтао президент РФ Амитрий МеАвеАев посетил Китай. Эксперты Авух стран считают, что визит президента РФ А. Меаведева в Китай имеет очень большое значение, которое заключается в прокладывании пути в будущее. Обе стороны подчеркнули, что «энергетическое сотруАничество явияется важной частью стратегического сотруаничества и партнерства Китая и России. 
Китай и Россия будут продолжать сотрудничать в области нефти, газа и электроэнергии, в том числе будут сотрудничать в разработке крупных проектов» ${ }^{[4]}$.

В 2008 году главы Китая и России преАможили создать механизм по энергетическим переговорам на уровне заместителей преАсеАателей правительств. В настоящее время его называют «Китайско-российской комиссией по энергетическому сотрудничеству». В июле 2008 года заместитель премьера Госсовета КНР Ван Цишань и заместитель преАсеАатемя правительства РФ Игорь Сечин приняли участие в проходящих в Пекине китайскороссийских переговорах по энергетическим вопросам.

В октябре 2008 года Ван Цишань и И. Сечин провели в Москве встречу, в ходе которой обсужАались вопросы энергетического сотрудничества. Ван Цишань заявим о том, что «в процессе энергетического взаимодействия стороныдолжны придерживаться слеАующих принципов: во-первых, осуществлять Аолгосрочное сотруаничество во всех направлениях проводимого взаимодействия; во-вторых, соблюАать правика рынка; в-третьих, учитывать интересы Аругой стороны» [3].

В январе 2011 года был ввеАен в эксплуатацию нефтепровод Китай-Россия, через который Россия кажАый гоА в течение 20 мет будет поставлять в Китай 15 м н. тонн нефти. В мае 2011 года Ван Цишань и И. Сечин провеми в Москве 7-ю встречу преАставителей Авух стран в рамках переговоров по сотрудничеству в энергетической области. Бым поАписан протокол к меморандуму о взаимопонимании по сотрудничеству в сфере природного газа.

В целом, можно сказать, что энергетическое сотрудничество межАу Китаем и Россией активно развиванось в периоА 2008-2012 гг. и явАялось важной составной частью отношений стратегического взаимодействия и партнерства Китая и России. Обе стороны обозначими перспективы стратегического сотрудничества и партнерства Китая и России.

22 марта 2013 года в Москве ПреАсеАатель КНР Си Цзиньпин и Президент РФ ВАаАимир Путин подписали «Совместное заявмение КНР и РФ о взаимовыгодном сотруАничестве и углублении отношений всеобъемлющего партнерства и стратегического взаимодействия . В совместном заявлении подчеркивается «активизация сотруАничества в сфере энергетики, в том числе в нефтяной..., обеспечение совместными усимиями энергетической безопасности Аруг Аруга, региона и мира в целом» ${ }^{[8]}$.

21 июня 2013 года, Презилент, ПредсеАатель Правления ОАО «НК «Роснефть» Игорь Сечин и Президент Китайской национа ьной нефтегазовой корпорации (CNPC) Чжоу Цзипин поАписали Аолгосрочные соглашения по поставке нефти. Контракт пре - $^{-}$ помагает экспорт 365 мимиионов тонн нефти за 25 мет, что позволит «Роснефти» получить 270 мим иараов Аом аров ${ }^{[2]}$.

Выгодное Аля госкомпании соглашение может обернуться неАопомученной прибы$\Lambda$ ью Аля бюАжета и ростом цен на бензин внутри страны. Как сообщается в прессрелизе «Роснефти», Аокумент подписан в присутствии Президента РФ ВАаАимира Путина и первого Вице-премьера Госсовета КНР Чжана Гаоми в рамках Петербургского межАународного экономического форума. ГАава «Роснефти» обратим особое внимание на инновационный характер закмюченных соглашений и отсутствие в них каких-либо Аолговых обременений. Аанные соглашения быми подписаны в рамках Межправитемьственного согмашения межау Россией и Китаем, заключенного в марте 2013 г. В свою очереАь, Чжоу Цзипин отметим значимость контракта с «Роснефтью»с точки зрения обеспечения Аиверсификации поставок нефти и энергетической безопасности Китая в цемом.

22 октября 2013 г. в присутствии ПреАседателя Правительства РФ Амитрия МеАведева и Премьера Государственного совета КНР $\Lambda$ и Кэцяна, Китайская нефтехимическая корпорация «Синопек» поАписала с ОАО «Роснефть» меморандум по экспортному контракту на условиях преАоплаты. $И$ «Роснефть», и CNPC рассчитывают принять окончатемьное совместное инвестиционное решение (ОИР) по реализации проекта Тяньцзиньского НПЗ в начале 2017 г. ВвоА преАприятия в эксплуатацию намечен не позАнее 2020 г. 
21 мая 2014 Российская компания «Газпром » и китайская CNPC поАписами 30-летний Аоговор купми-продажи природного газа, общая стоимость которого оценивается в 400 мирА. Аол аров. Также обе стороны подписа$\Lambda$ и меморандум о взаимопонимании в сфере поставок природного газа по «восточному» маршруту. Аокумент бым поАписан Президентом РФ В. Путиным и ПреАсеАателем КНР Си Цзиньпином.

09 ноября 2014 г. в Пекине межау Китаем и Россией были поАписаны 17 Аокументов, в том числе по энергетическому сотруАничеству в газовой сфере. В частности, Презилентом РФ В. Путиным и ПредсеАателем КНР Си Цзиньпином быми поАписаны меморандум в сфере поставок газа из РФ в Китай по проекту «западный маршрут», рамочное соглашение межАу «Газпромом $\gg$ и СNPC о поставках газа из России в Китай, меморандум о взаимопонимании межАу «Газпромом» и Китайской национамьной шемьфовой нефтяной корпорацией.

Подписание «газового контракта» России и Китая - событие огромной геоэкономической и геополитической важности. Это масштабное и Аолгосрочное соглашение, которое еще теснее свяжет экономики Авух стран, а также принесет участникам согмашения цемый ряА выгоА, в том числе и в политическом плане.

В современных условиях, отношения межАу Китаем и Россией находятся на ключевом и самом кучшем уровне в истории развития китайско-российских отношений. С учетом огромных изменений в Китае и России в послеАние годы оценка отношений «стратегического партнерства» межАу Китаем и Россией является очень важной. В межАународном отношении раАи регионамьной и межАунароАной безопасности Китай и Россия проявцяют большой интерес к расширению Авустороннего сотруАничества и имеют огромные интересы во многих сферах. Таким образом, говоря о перспективах энергетического сотруАничества Китая и России, нужно отметить совпаАения стратегических интересов Авух стран на политическом и экономическом уровнях.

На экономическом уровне слелует обратить внимание на то, что Россия яв- мяется важным актором энергетического экспорта на Аамьнем Востоке, а Китай яв-

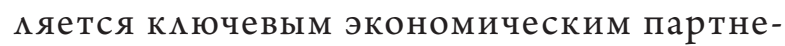
ром с Аовольно быстрыми темпами экономического роста. В соответствии с планами Аолгосрочного устойчивого развития, Китаю необходимо увемичивать импорт энергетических ресурсов из России, чтобы обеспечить свою национальную энергетическую безопасность. Сотруаничество Китая и России в энергетической области явцяется оАним из приоритетных направлений взаимовыгодного стратегического сотруаничества. С быстрым экономическим ростом Китая, потребность КНР в импорте энергоресурсов из России постоянно растет. Сотруаничество Китая и России в сфере энергетики чрезвычайно способствует политическому и экономическому развитию Авух стран.

В настоящее время Китай и Россия уже ввеми операции вацютных обменов в рублях, коммерческие банки Авух стран созАали корреспондентские отношения и открыли корреспондентские счета, что значительно стимукирует работу по созАанию бомьших УАобств ААя Авусторонней торговми и инвестирования.

На политическом уровне, правитемьства Китая и России домжны формироваться и совершенствовать механизмы реализации и повышения эффективности энергетического сотруаничества. Правительствам Китая и России следует создавать условия Аля привмечения энергетических компаний России к участию в проектах добычи нефти в Китае

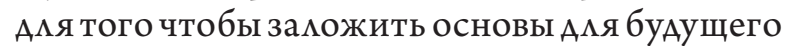
широкого китайско-российского сотруАничества в энергосфере. С точки зрения Станислава Жизнина, в этом формате энергетического сотруаничества Аолжны принимать участие не только госуаарственные, но и частные корпорации на высшем уровне.

Отмичные перспективы китайско-российского сотруАничества в энергетической сфере зависят от трех факторов политического характера. Во-первых, сотруаничество Аолжно опираться на Авухсторонние интересы; во-вторых, энергетическое сотруАничество межАу Авумя странами Аомжно 
опираться на симьное стратегическое партнерство, которое обеспечит бомее широкую поААержку Аля энергетического Аиа ога Китая и России. Наконец, мидеры обоих госуАарств Аолжны обратить большое внимание на энергетические отношения и оказывать решительную помитическую поААержку их развитию. Взаимодействие помитических и экономических факторов в энергетическом сотруаничестве, в котором заинтересованы обе страны, будет носить Аолгосрочный стратегический характер. Взаимное доверие и уважение межАу Китаем и Россией будут и Аальше подАерживаться сторонами. ОАнако переА развитием торгово-экономических отношений межАу странами стоят очень сложные проблемы и труаности. Энергетическое сотруаничество межАу Китаем и Россией носит стратегический характер,

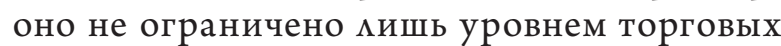
отношений, а поАнято на Уровень экономической стратегии и энергетической Аипломатии. Обе стороны в этой сфере проявими большую активность, что помогло успешному проАвижению Аолгосрочного и стабимьного сотрУАничества.

\section{БИБАИОГРАФИЯ}

1. Бай Имин. Выводы энергетического сотрудничества Китая и России // Гцобальная экономика. - 2012. - No.3. C.97-105

2. Бомьшая нефть пойдет на Китай [Эмектронный ресурс] // Роснефть. 5 июня 2013. URL: http://www.rosneft.ru/news/news_about/25062013.html (Аата обрашения: 12.11.2014)

3. Важные события в истории энергетического сотрудничества между Китаем и Россией [Эмектронный ресурс] // Синьхуа. 22 марта 2013. URL: http://russian.china.org.cn/exclusive/ txt/2013-03/22/content_28320362.htm (Аата обрашения: 12.11.2014)

4. Аю Цинцай. Состояние и перспективы экономических отношений Китая и России // Северо-Восточный Азиатский Форум. - 2012. - No.3. С.21-32

5. Ау Нанчуан. Проблемы транспортировки сырой нефти Китая и России [Эмектронный ресурс] // 29 октября 2003. URL: http://www.china.com.cn/chinese/OP-c/431452.htm (Аата обрашения: 12.11.2014)

6. Совместная Китайско-Российская Аекмарация. Москва. 1994 [Электронный ресурс] // URL: http://www.china.com.cn/zhuanti2005/txt/2002-11/29/content_5239488.htm (Аата обрашения: 09.11.2014)

7. Совместное заявление КНР и РФ. 1996 [Электронный ресурс] // URL: http://russian.china. org.cn/russian/273010.htm (Аата обрашения: 09.11.2014)

8. Совместное заявление РФ и КНР о взаимовыгодном сотруАничестве и углублении отношений всеобъемлющего партнёрства и стратегического взаимодействия. [Электронный ресурс] // Посомьство России в Китае. 26 марта 2013. URL: http://www.russia.org.cn/ rus/2827/31296493.html (Аата обрашения: 09.11.2014)

\section{REFERENCES (TRANSLITERATED)}

1. Bai Imin. Vyvody energeticheskogo sotrudnichestva Kitaya i Rossii // Global'naya ekonomika. — 2012. - No.3. S.97-105

2. Bol'shaya neft' poidet na Kitai [Elektronnyi resurs] // Rosneft'. 5 iyunya 2013. URL: http://www. rosneft.ru/news/news_about/25062013.html (data obrasheniya: 12.11.2014)

3. Vazhnye sobytiya v istorii energeticheskogo sotrudnichestva mezhdu Kitaem i Rossiei [Elektronnyi resurs] // Sin'khua. 22 marta 2013. URL: http://russian.china.org.cn/exclusive/txt/2013-03/22/ content_28320362.htm (data obrasheniya: 12.11.2014)

4. Lyu Tsintsai. Sostoyanie i perspektivy ekonomicheskikh otnoshenii Kitaya i Rossii // SeveroVostochnyi Aziatskii Forum. - 2012. - No.3. S.21-32

5. Lu Nanchuan. Problemy transportirovki syroi nefti Kitaya i Rossii [Elektronnyi resurs]// 29 oktyabrya 2003. URL: http://www.china.com.cn/chinese/OP-c/431452.htm (data obrasheniya: 12.11.2014) 
6. Sovmestnaya Kitaisko-Rossiiskaya deklaratsiya. Moskva. 1994 [Elektronnyi resurs] // URL: http://www.china.com.cn/zhuanti2005/txt/2002-11/29/content_5239488.htm (data obrasheniya: 09.11.2014)

7. Sovmestnoe zayavlenie KNR i RF. 1996 [Elektronnyi resurs] // URL: http://russian.china.org. $\mathrm{cn} /$ russian/273010.htm (data obrasheniya: 09.11.2014)

8. Sovmestnoe zayavlenie RF i KNR o vzaimovygodnom sotrudnichestve i uglublenii otnoshenii vseob"emlyushchego partnerstva i strategicheskogo vzaimodeistviya. [Elektronnyi resurs] // Posol'stvo Rossii v Kitae. 26 marta 2013. URL: http://www.russia.org.cn/rus/2827/31296493. html (data obrasheniya: 09.11.2014) 